\title{
NILAI-NILAI BUDAYA LOKAL DALAM MEMBANGUN PERSATUAN DAN KESATUAN PESERTA DIDIK SMA YPKM MANADO
}

\author{
Hetreda Terry
}

Fakultas Ilmu Sosial,

Universitas Negeri Manado

hetredaterry@unima.ac.id

\begin{abstract}
Abstrak
Nilai-nilai Budaya lokal dalam membanagun persatuan dan kesatuan peserta didik yang ada di SMA YPKM Manado perlu dibangun dengan melihat kenyataan peserta didik memiliki latar belakang suku, tradisi, ekonomi, karakter dan adat istiadat yang berbeda. Mereka adalah generasi penerus bangsa yang harus memaknai dengan baik dan benar perjuangan para leluhur bangsa merebut kemerdekaan bangsa. Mereka hidup di Persatuan dan kesatuan bangsa yang telah dibangun oleh para pendiri bangsa perlu dipelihara dan dilestarikan. Berbagai cara bisa digunakan atau dilakukannya. Salah satu cara yang dipakai untuk membangun persatuan dan kesatuan antar peserta didik yang memiliki latar belakang yang berbeda adalah melalui nilai-nilai budaya lokal yang ada di lingkungan masyarakat. Nilai-nilai budaya lokal yang ada antara lain : Kumaus, Pengucapan syukur, Sitou Timou Tumou Tou dan Torang Samua Basudara. Tujuan kegiatan ini untuk membangun persatuan dan kesatuan peserta didik di SMA YPKM Manado. Metode pelaksanaan kegiatan ini adalah sosialisasi dan penyuluhan. Khalayak sasaran kegiatan ini adalah peserta didik. Hasil yang dicapai : 1) peningkatan pengetahuan tentang nilai-nilai budaya lokal setempat; 2) memperoleh pengetahuan tentang makna nilai budaya lokal Sitou Timou Tumou Tou dan Torang samua basudara, kumaus dan pengucapa syukur dalam merajut persatuan dan kesatuan.
\end{abstract}

Kata Kunci: Nilai-Nilai Budaya Lokal, Persatuan dan kesatuan, peserta didik. 


\section{PENDAHULUAN}

Peserta didik yang ada di SMA YPKM Manado, berdasarkan data yang ada memiliki latar belakang suku, budaya, karakter yang berneka ragam. Itulah sebabnya amatlah perlu memberikan pemahaman tentang hidup kebersamaan dengan tidak melihat latar belakang yang dimiliki masing-masing. Apalagi mereka hidup dan mengenyam pendidikan di kota Manado yang memiliki nilia-nilai budaya lokal yang dapat dijadikan pedoman dalam membangun persatuan dan kesatuan.

Untuk itu perlu ada pemahaman sedini mungkin tentang pentingnya membangun kebersamaan dalam persatuan dan kesatuan bangsa yang perlu dipupuk dari lingkungan tempat peserta didik menimbah ilmu pengetahuan dan teknologi. Dengan memahami makna dari slogan "Torang Samua Basudara; Sitou Timou Tumou Tou; serta budaya Kumaus dan pengucapan syukur. Nilai-nilai tersebut akan membekali setiap insan yang mendiami bumi Nyiur melambai pada umumnya dan masyarakat kota Manado pada khususnya dalam mendukung program pemerintah menjaga kedamaian melalui persatuan dan kesatuan bangsa. Tujuan kegiatan ini adalah memaknai dengan baik dan benar makna kearifan lokal dalam merajut persatuan dan kesatuan bagi mahasisiwa Jurusan Pendidikan Sejarah Fakultas Ilmu Sosial Universitas Negeri Manado.

\section{METODE PELAKSANAAN}

Pelaksanaan Program PKM pada Mahasisiwa Jurusan Pendidikan Sejarah dilakukan dengan metode:

1). Sosialisasi; Kegiatan sosialisasi lebih ditekankan kepada pemberian pemahaman dan pengertian kepada mahasiswa tentang pentingnya merajut persatuan dan kesatuan melalui nilai-nilai budaya lokal yang ada di kota manado. Metode ini memungkinkan peserta didik dapat berdiskusi, saling berbagi informasi, tentang nilai-nilai budaya lokal yang ada di daerah dari mana mereka datang, yang ada yang ada kesamaannya dengan budaya lokal yang ada di kota Manado, seperti Sitou Timou Tumou Tou, Torang Samua Basudara, Kumaus dan budaya pengucapan syukur.

2). Penyuluhan: Dalam kegiatan ini diberikan pengetahuan tentang budaya lokal yang dapat menjadi media atau alat dalam membangun persatuan dan kesatuan masyarakat Indonesia yang sangat heterogen, sebagaimana yang nampak pada peseta didik yang sementara menikmati pendidikan di SMA YPKM Manado. Dengan memaknai dengan baik dan benar nilai-nilai budaya lokal masyarakat setempat diharapkan mampu membangun persatuan dan kesatuan antara peserta didik yang datang dari berbagai daerah dengan latar belakang yang berbeda.

Khalayak sasaran dari kegiatan ini adalah peserta didik yang ada di SMA YPKM Manado. 


\section{HASIL DAN PEMBAHASAN}

Hasil

Melalui kegiatan PKM pada peserta didik yang ada di SMA YPKM Manado, halhal yang telah dicapai adalahPeserta didik sebagai berikut:

1. Peningkatan pegetahuan tentang nilainilai budaya lokal yang ada di daerah Sulawesi Utara lebih khusus di kota Manado.

2. Peningkatan Pengetahuan tentang nilai-nilai budaya lokal yang dapat membangun persatuan dan kesatuan diantara peserta didik pada khususnya dan masyarakat kota Manado pada umumnya,.

3. Terdapat 3 peserta didik yang berasal dari luar kota Manado yang mampu menjelaskan kesamaan $\mathrm{n}$ antara nilai budaya lokal yang ada didaerahnya dengan yang ada di daerah kota Manado.

\section{Pembahasan}

Haryati Soebadio berpendapat bahwa kearifan lokal adalah suatu identitas/kepribadian budaya bangsa yang menyebabkan bangsa tersebut mampu menyerap dan mengolah kebudayaan asing sesuai watak dan kemampuan sendir. Menurut Rahyono (2009:7) kearifan lokal merupakan kecerdasan manusia yang dimiliki oleh kelompok etnis tertentu yang diperoleh melalui pengalaman masyarakat. Artinya, kearifan lokal adalah hasil dari masyarakat tertentu melalui pengalaman mereka dan belum tentu dialami oleh masyarakat yang lain. Nilai-nilai tersebut akan melekat sangat kuat pada masyarakat tertentu dan nilai itu sudah melalui perjalanan waktu yang panjang, sepanjang keberadaan masyarakat tersebut. Kearifan lokal itu bersifat dinamis, lentur, terbuka, dan senantiasa menyesuaikan dengan zamannya.

Kearifan lokal adalah bagian dari budaya. Kearifan lokal Minahasa tentu bagian dari budaya Minahasa, yang memiliki pandangan hidup tertentu. Kearifan lokal lebih menekankan pada tempat dan lokalitas dari kearifan tersebut sehingga tidak harus merupakan sebuah kearifan yang telah diwariskan dari generasi ke generasi. Kearifan lokal bisa merupakan kearifan yang belum lama muncul dalam suatu komunitas sesuai dengan situasi dan kondisi masyarakat setempat, sebagai contoh kearifan Torang Samua Basudara, muncuul saat E. Mangindaan menjadi Gubernur Sulawesi Utara. Oleh karena itu, kearifan lokal tidak selalu bersifat tradisional karena dia dapat mencakup kearifan masa kini dan karena itu pula lebih luas maknanya. Secara mendalam nilai budaya Torang Samua Basudara mengandung dimensi-dimensi sebagai berikut:

- Menjadikan nilai Torang Samua Basudara sebagai the way of life (cara dan pandangan hidup).

- Menjunjung tinggi rasa toleransi. 
- Rasa hormat kepada orang tanpa memandang latar belakang, suku, tradisi, ras, dan keyakinan

- Siap membantu sesama tanpa memandang latar belakang.

- Menyelesaikan masalah dengan kepala dingin dan mengedepankan demokrasi

- Nilai budaya Torang Samua Basudara , dapat disimpulkan bahwa masyarakat SULUT dalam kehidupan setiap hari tidak pernah memandang perbedaan, suku, bahasa sebagai halangan untuk berelasi dengan orang lain. Masyarakat dari latar belakang apa pun dianggap saudara yang harus dihargai hakikatnya sebagai manusia ciptaan Tuhan.

Kegiatan semacam ini perlu dilaksanakan secara terus-menerus baik itu dalam program PKM atau program Pengabdian Masyarakat yang lain untuk terus membangun kebersamaan dalam merajut persatuan dan kesatuan dikalangan masyarakat Indonesia pada umumnya dan generasi muda pada khususnya.

\section{KESIMPULAN}

Hasil kegiatan ini memberikan nilai positif terhadap peserta didik sebagai generasi muda dengan memaknai nilai budaya lokal yang tumbuh dan berkembang di berbagai daerah yang dapat dijadikan media dalam membangun persatuan dan kesatuan bangsa.

\section{KEPUSTAKAAN}

Kansil, C.S.T dan Christine S.T. Kansil. 2011. Empat Pilar Berbangsa dan Bernegara. PT. Rineka Cipta; Jakarta. 271 hal.

Pasandaran Sjamsi, 2004,

Demokratisasi Pendidikan

: Menjawab Tantangan Manajemen

Pendidikan Nasional, Media Pustaka

Manado, ' 190 hal.

Tilaar, H. A. R. 2004. Multikulturalisme

: Tantangan - tantangan Global Masa

Depan Dalam Transformasi

Pendidikan Nasional. PT Gramedia

Wisiasarana Indonesia; Jakarta. 401

hal. 